\title{
Agronomic performance of the Maciel peach with different rootstocks
}

\section{Desempenho agronômico de pessegueiro Maciel sobre diferentes porta-enxertos}

\author{
Caroline Farias Barreto ${ }^{1 *}$; Marines Batalha Moreno Kirins ${ }^{1}$; \\ Pricila Santos da Silva ${ }^{1}$; Carina Radmann Schiavon ${ }^{2}$; \\ Cesar Valmor Rombaldi³; Marcelo Barbosa Malgarim; José Carlos Fachinello ${ }^{4}$
}

\begin{abstract}
The rootstock influences the agronomic performance of fruit plants. In Prunus persica (peach), particularly those varieties produced in Brazil, this relationship is not well understood. We, therefore, set out to evaluate the performance of the peach cultivar Maciel with eight rootstocks, Aldrighi, Capdeboscq, Flordaguard, Nemaguard, Okinawa, Umezeiro, Tsukuba, and Seleção Viamão, planted in 2006 and evaluated in the 2014/2015 and 2015/2016 seasons. Phenology of flowering, trunk diameter, canopy volume, fruit number, and yield were evaluated in the field. For the fruit, we evaluated the mass, diameter, color, flesh firmness, soluble solids concentration, titratable acidity, concentration of total phenolic compounds, carotenoids, and antioxidant activity. Plants from the Aldrighi and Nemaguard rootstocks flowered earlier than plants from the other rootstocks in 2014, and in 2015, flowering was variable in all rootstocks. The cultivar Maciel on Umezeiro had low vigor, trunk diameter, and canopy volume. On Aldrighi, Capdeboscq, Flordaguard, Nemaguard, and Tsukuba this cultivar showed good production rates. The fruit color, flesh firmness, concentration of soluble solids, total phenolics, antioxidant activity, and total carotenoids were influenced by rootstock and harvest.
\end{abstract}

Key words: Fruit quality. Vegeto-productive behavior. Phytochemicals. Prunus persica (L.). Batsch.

\section{Resumo}

O porta-enxerto influencia o desempenho agronômico de plantas frutíferas. Porém, em pessegueiro, especialmente para as cultivares produzidas no Brasil, essa relação não está bem elucidada. Por isso, propôs-se avaliar o desempenho de oito porta-enxertos 'Aldrighi', 'Capdeboscq', 'Flordaguard', 'Nemaguard', 'Okinawa', 'Umezeiro', 'Tsukuba' e 'Seleção Viamão' sob pessegueiros da cultivar 'Maciel', plantados em 2006, e avaliados nas safras 2014/2015 e 2015/2016. As variáveis avaliadas a campo foram fenologia da floração, diâmetro de tronco, volume de copa, número de frutos e produtividade. Nos frutos avaliou-se a massa, o diâmetro, a coloração, a firmeza de polpa, a concentração de sólidos solúveis totais, a acidez titulável, a concentração de compostos fenóis totais, de carotenóides totais e a atividade antioxidante. Os porta-enxertos 'Aldrighi' e 'Nemaguard' anteciparam o início da floração em 2014 e no ano de 2015 os porta-enxertos induziram desuniformidade na floração dos pessegueiros. O porta-enxerto 'Umezeiro' induz menor vigor, diâmetro de tronco e volume de copa. Os porta-enxertos

\footnotetext{
${ }^{1}$ Discentes, Programa de Pós-Graduação em Agronomia, Universidade Federal de Pelotas, UFPel, Pelotas, RS, Brasil. E-mail: carolfariasb@hotmail.com; marinesfaem@gmail.com

2 Discente do Curso de Agronomia, UFPel, Pelotas, RS, Brasil. E-mail: carina-schiavon@hotmail.com

${ }^{3}$ Prof., Departamento de Ciência e Tecnologia Agroindustrial, UFPel, Pelotas, RS, Brasil. E-mail: cesarvrf@ufpel.edu.br

${ }^{4}$ Profs., Departamento de Fitotecnia, UFPel, Pelotas, RS, Brasil. E-mail: malgarim@ufpel.edu.br; jfachi@ufpel.edu.br (in memorian).

* Author for correspondence
} 
'Aldrighi', 'Capdeboscq', 'Flordaguard', 'Nemaguard' e 'Tsukuba' induziram bons índices produtivos. A coloração dos frutos, firmeza de polpa e a concentração de sólidos solúveis, fenóis totais, atividade antioxidante e carotenóides totais foram influenciados pelo porta-enxerto e pela safra.

Palavras-chave: Comportamento vegeto-produtivo. Fitoquímicos. Qualidade de frutos. Prunus persica (L.). Batsch.

\section{Introduction}

The peach tree is cultivated in several Brazilian states, with the commercial cultivation concentrated in the states of Rio Grande do Sul, São Paulo, Santa Catarina, Minas Gerais, and Paraná. In the south of the country, peach production amounts to approximately 170 thousand tons, of which 136 thousand tons are produced in Rio Grande do Sul (IBGE, 2015).

To meet the market demand for peaches, cultivation in Rio Grande do Sul depends on the optimization of canopy and rootstock combinations to increase yield and fruit quality. Most peach orchards use seed-bearing rootstocks, traditionally from the canning industry. However, these materials are genetically variable, leading to a lack of uniformity in the plants and hindering orchard management. In general, Aldrighi and Capdeboscq rootstocks are most commonly used (ROCHA et al., 2007). Other rootstocks have also been studied, including Flordaguard, Nemaguard, Okinawa, Umezeiro, and Seleção Viamão (COMIOTTO et al., 2012; GALARÇA et al., 2013; COMIOTTO et al., 2013). Advantageously, the rootstocks Okinawa, Nemaguard, and Tsukuba tend toward vigorous canopy growth in peach trees, Flordaguard tolerates cold, Okinawa has rapid initial growth and produces fruit early (MAYER et al., 2014), and Umezeiro, with low plant vigor, represents an alternative for orchard densification management (GALARÇA et al., 2013).

Knowledge about the performance of rootstock/ canopy cultivar combinations is essential for the selection of suitable plant material prior to orchard planting (SCHMITZ et al., 2012). The study of different rootstocks as an alternative to those currently widely used in southern Brazil is essential to identify compatible combinations and to evaluate vegetative and productive characteristics as well as the quality and phytochemical characteristics of the fruit. The present study, therefore, has been undertaken with the goal of evaluating the performance of eight rootstocks grafted with peach trees of the Maciel cultivar with regard to the vegetative growth, production, and quality characteristics of the peaches.

\section{Material and Methods}

The experiment was conducted in a teaching orchard at the Palma Agricultural Center (Centro Agropecuário da Palma; CAP) belonging to the Federal University of Pelotas (Universidade Federal de Pelotas) in the municipality of Capão do Leão, in the state of Rio Grande do Sul (latitude 31 ${ }^{\circ} 52^{\prime} 00^{\prime \prime}$ $\mathrm{S}$ and longitude $\left.52^{\circ} 21^{\prime} 24^{\prime \prime} \mathrm{W}\right)$. According to the classification of Köppen, the climate of the region is type Cfa, namely humid and temperate with hot summers. The region has an average annual rainfall and temperature of $1500 \mathrm{mmand} 17.9^{\circ} \mathrm{C}$, respectively. The mean temperature, mean precipitation, and cold hours during the experimental period were collected from the Embrapa Temperate Climate (Embrapa Clima Temperadas) meteorological station at the Terras Baixas experimental station that is located in the municipality of Capão do Leão, Rio Grande do Sul. The cold hours were calculated based on temperatures below or equal to $7.2^{\circ} \mathrm{C}$.

The experiment was conducted during the 2014/2015 and 2015/2016 harvests. The peach orchard used consisted of the P. persica (L.) Batsch Maciel cultivar grafted onto Aldrighi, Capdeboscq, Flordaguard, Nemaguard, Okinawa, Umezeiro, Tsukuba, and Seleção Viamão rootstocks. The 
orchard was planted in 2006 with a "V" type plantorganization system with $5 \mathrm{~m}$ of space between rows and $1.5 \mathrm{~m}$ between plants, amounting to a density of 1.333 plants $\mathrm{ha}^{-1}$. The experimental design involved randomized blocks, with each plot being composed of five plants. The plants at the ends of each plot were disregarded, amounting to nine useful plants.

The variables evaluated in the field were: trunk diameter (mm), measured at $20 \mathrm{~cm}$ above the soil surface in two transverse positions with the aid of a digital caliper; canopy volume $\left(\mathrm{m}^{3}\right)$, calculated according to Rossi (2004) using the equation $\mathrm{V}=$ $[(\mathrm{L} / 2) \times(\mathrm{E} / 2) \times \mathrm{A} \times \pi] / 3$, where " $\mathrm{V}$ " is the volume of the canopy, "L" the distance between the main branches, "E" the average thickness of the main branches, and " $A$ " the height of the canopy.

Flowering was evaluated by subperiods including early flowering when $10 \%$ of the flowers were open, full bloom when $50 \%$ to $70 \%$ of the flowers were open, late flowering when the petals were falling, and early sprouting when $10 \%$ of the fruit were formed. Fruit were monitored until harvest time when the number of fruit per plant (fruit plant ${ }^{-1}$ ) and productivity ( $\mathrm{t} \mathrm{ha}^{-1}$ ) were evaluated to determine production amounts.

After harvesting, the fresh weights (grams) of the peaches were evaluated by digitally weighing 20 fruit per repetition, totaling 60 fruits. The firmness of the pulp (Newtons), was measured at two opposite points in the equatorial region of peeled fruit using a manual penetrometer (model 53205, TR TURONIItaly) with an $8 \mathrm{~mm}$ tip; the color of the epidermis was examined using a colorimeter type Minolta CR$300^{\circledR}$, with a D65 light source that measured "L" (luminosity), "a*", " $b^{*}$, and the hue or chromatic tonality represented by the "hue angle"; the total soluble solids ( ${ }^{\circ}$ Brix) were measured using an Atago digital refractometer ${ }^{\circledR}$; and the total titratable acidity (\% citric acid) was quantified in $10 \mathrm{~mL}$ of juice diluted in $90 \mathrm{~mL}$ of distilled water and titrated with $0.1 \mathrm{~mol} \mathrm{~L} \mathrm{NaOH}$ solution to $\mathrm{pH} 8.1$ with the aid of the Quimus pHmeter ${ }^{\circledR}$.
The following analyses were performed to determine the phytochemicals in peach pulp. Total phenolic compounds (mg Gallic acid per $100 \mathrm{~g}$ of sample) were determined according to the adapted method of Singleton and Rossi 1965 using the reaction with the Folin-Ciocalteau reagent; total carotenoids ( $\mathrm{mg} \beta$-carotene in $100 \mathrm{~g}$ of sample) were determined using the modified method of AOAC (2005) and an extraction solution (hexaneacetone-alcohol-toluene); and antioxidant activity (mg trolox per $100 \mathrm{~g}$ fresh weight) was determined using the radical DPPH method adapted from BrandWilliams et al. (1995). The data were evaluated for normality (Shapiro-Wilk test) and homoscedasticity (Hartley test) and then submitted to a variance analysis (F-Test), with the means compared using Tukey's range test to identify significant differences $(\mathrm{p} \leq 0.05)$.

\section{Results and Discussion}

In the 2014/2015 harvest season, development, growth, and flowering of the peach trees occurred under climatic conditions similar to those of southern Rio Grande do Sul. This was determined by comparing the conditions to historically average years in places known for orchard management (Figure 1). However, the 2015/2016 harvest season was strongly influenced by an El Niño phenomenon that determined the different behavior of canopy and rootstock combinations. The flowering of the peach trees occurred uniformly and in a concentrated manner in the 2014/2015 harvest season (Figure 2A), while in the $2015 / 2016$ harvest season, there was variability observed in all rootstocks with regard to the timing of the beginning, peak, and end of flowering. This was likely caused by the increased temperatures in the month of July to August (Figure 2B).

In the 2014/2015 harvest season, the Maciel peach trees on Aldrighi and Nemaguard rootstocks started flowering on July 7, 2014, seven days earlier than the beginning of flowering in the 
other rootstocks. Full bloom of all the peach trees occurred on July 28, 2014, excluding the plants on the Umezeiro rootstock that reached full bloom on July 21, 2014. Although there were differences in the flowering period between rootstocks, the maturation of the fruits occurred in a similar way regardless of the rootstock; that is, the harvest peak on October 12, 2014, for all trees examined.

In the 2015/2016 harvest season, determination of the phenological flowering subperiods of the Maciel cultivar was impaired because sprouts, flowers, and fruit were detected on the same branch at the same time, indicating variability in flowering, regardless of the rootstock. Historically, in the region where the experiment was conducted, flowering of the Maciel cultivar occurs in late July to early August (Raseira et al., 2014). However, in the 2015/2016 harvest season, the peach blossoms occurred irregularly, beginning about a month before late July. Specifically, flowering began on August 6, 2015, in the plants with Tsukuba, Okinawa, and Umezeiro rootstocks and on June 12, 2015, in the plants on the other rootstocks. After this first flowering, flower loss occurred in all rootstocks because of oscillations in the temperature. The influence of the El Niño conditions that included an increase in the mean temperature and greater precipitation during the flowering period was observed, and in turn, caused changes in the duration of the phenological phases of the plant. On July 28, 2015, a second flowering occurred with fewer flowers in the Maciel peach trees on all rootstocks. This is likely to have occurred because 2015 had only 141 hours of cold and had extensive temperature fluctuations during the winter. The Maciel cultivar requires 200 to 300 hours of accumulated winter cold to flower properly (RASEIRA et al., 2014).

There are reports that the phenology observed in the Maciel cultivar varies per crop. For example, in the same orchard (municipality of Capão do Leão, Rio Grande do Sul), Galarça (2013) observed that flowering came early in the Maciel cultivar on
Aldrighi, Capdeboscq, Umezeiro, Nemaguard, and Okinawa rootstocks in 2010 and on Aldrighi, Capdeboscq, Umezeiro and Okinawa rootstocks in 2011. The Aldrighi and Nemaguard rootstocks began flowering early and Umezeiro came into full bloom early in the 2014/2015 harvest season. Conversely, the flowering time was variable for all the rootstocks in the 2015/2016 harvest season, with two separate flowering periods occurring.

There are reports that the phenology observed in the Maciel cultivar varies per crop. For example, in the same orchard (municipality of Capão do Leão, Rio Grande do Sul), Galarça (2013) observed that flowering came early in the Maciel cultivar on Aldrighi, Capdeboscq, Umezeiro, Nemaguard, and Okinawa rootstocks in 2010 and on Aldrighi, Capdeboscq, Umezeiro and Okinawa rootstocks in 2011. The Aldrighi and Nemaguard rootstocks began flowering early and Umezeiro came into full bloom early in the 2014/2015 harvest season. Conversely, the flowering time was variable for all the rootstocks in the 2015/2016 harvest season, with two separate flowering periods occurring.

The trunk diameter of Maciel peach plants varied between the harvests, with no differences observed between rootstocks in the 2014/2015 harvest season while in the 2015/2016 harvest season differences were observed. In this season, the diameter of the Aldrighi rootstock was larger than both Viamão and Umezeiro although it did not differ from the other rootstocks in terms of size (Table 1). In addition to a smaller trunk diameter, the Umezeiro rootstock resulted in lower canopy volume in both harvest seasons. While we observed differences between the trunk thickness of the rootstocks and the graft, suggesting that there is little affinity between the cultivars, an anatomical study is required to confirm this incompatibility. The smaller trunk diameter, plant vigor, and canopy volume results observed here are consistent with those reported by Comiotto et al. (2013) and Galarça et al. (2013). 
Figure 1. Average temperature, hours of cold, and amount of precipitation in 2014 and 2015 for Capão do Leão, Rio Grande do Sul. Provided by the Terras Baixas Experimental Station, Temperate Climate Embrapa, at the Capão do Leão municipality, Rio Grande do Sul, 2016.
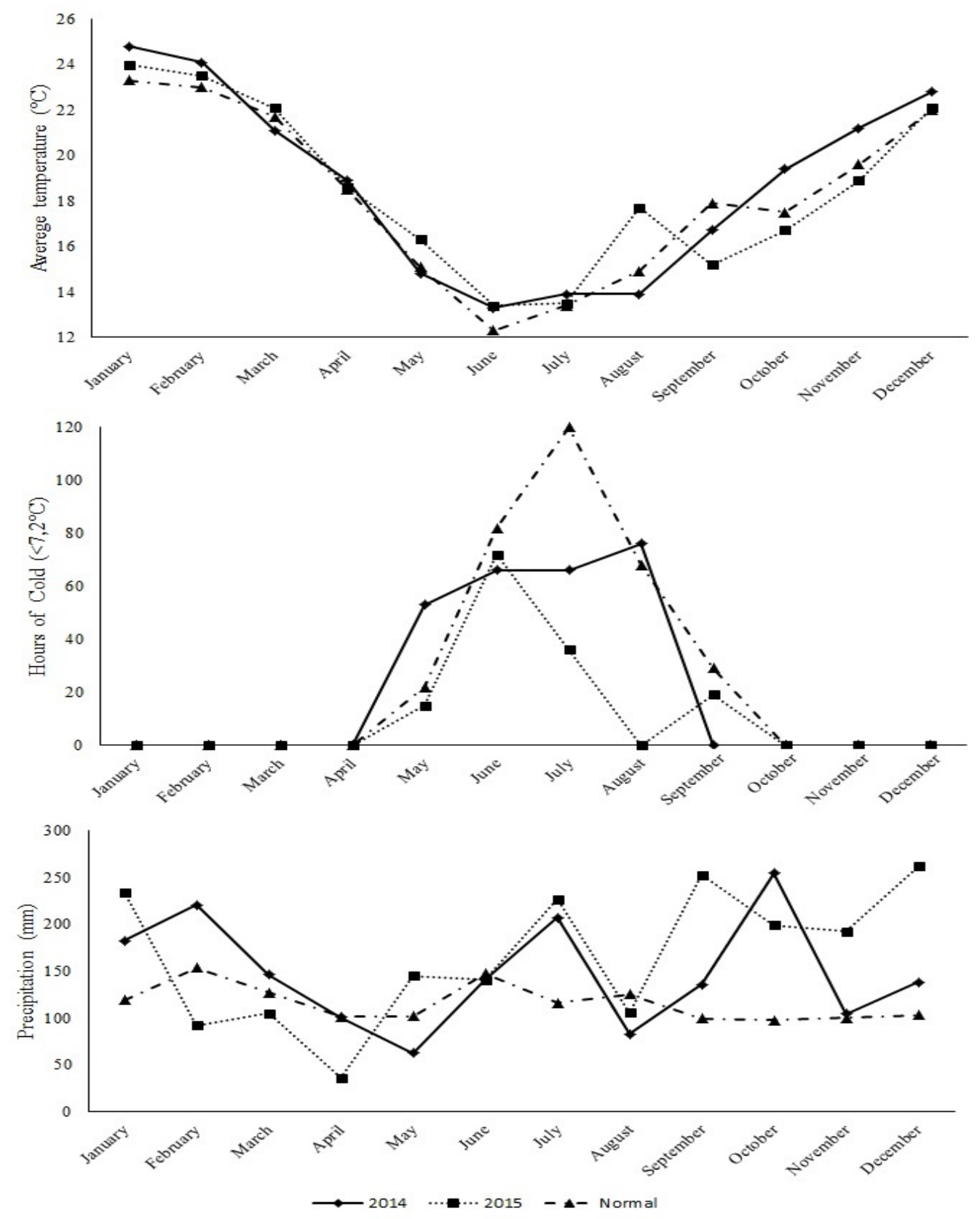

The smaller trunk diameter and canopy volume in Maciel peach trees grafted onto Umezeiro is likely caused by both the lack of affinity between these cultivars at the grafting point and the nutrient absorption capacity of the root system. Tombesi et al. (2011) observed a lack of affinity between peach tree canopies and rootstocks that resulted in smaller xylem capacities and reduced hydraulic conductance. 
Figure 2. Dates of early, full bloom, late flowering, and early sprouting of Maciel peach trees grafted on different rootstocks, in the municipality of Capão do Leão, Rio Grande do Sul for the 2014/2015 (A) and 2015/2016 (B) harvest seasons.
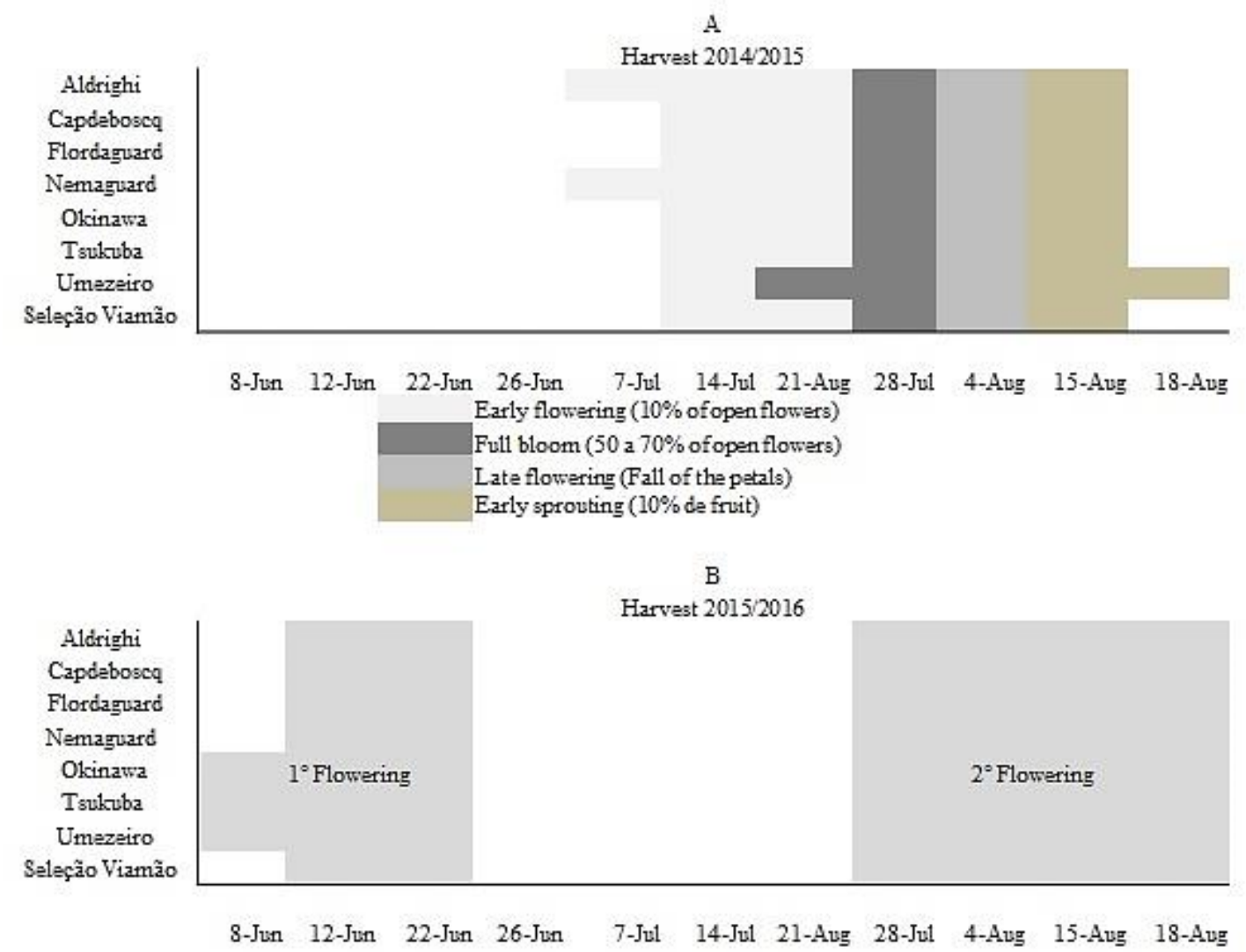

The smaller trunk diameter and canopy volume in Maciel peach trees grafted onto Umezeiro is likely caused by both the lack of affinity between these cultivars at the grafting point and the nutrient absorption capacity of the root system. Tombesi et al. (2011) observed a lack of affinity between peach tree canopies and rootstocks that resulted in smaller xylem capacities and reduced hydraulic conductance.

The peach trees showed higher average fruit numbers when grafted onto all rootstocks except for Umezeiro in both harvest seasons (Table 1). There, however, were fewer fruit in the 2015/2016 crop than in the previous one because of the mild winter conditions that resulted in unfavorable temperatures at flowering and a late frost (Figure 1).

The rootstocks Aldrighi and Capdeboscq are traditionally used in the southern region of Rio Grande do Sul because they provide good productivity (RASEIRA et al., 2014). Other rootstocks were also observed to have high productivity with the Maciel cultivar in the 2014/2015 harvest season, namely the Flordaguard, Nemaguard, Tsukuba, and Okinawa rootstocks. Greater productivity was also observed in the 2015/2016 harvest season for Flordaguard, Nemaguard, and Aldrighi, although no difference was observed with Capdeboscq and Tsukuba. Aldrighi and Capdeboscq have been used as peach rootstocks since the 1940s and are found in abundance in the canning industry. The pits of these cultivars came from plants that were grown over time as a canopy variety because of their greater edaphoclimatic adaptation and late maturation. Currently, commercial orchards of these two cultivars are rarely found because the availability of their pits is limited (MAYER et al., 2014). 
Table 1. Trunk diameter (TD), canopy volume (CV), number of fruit per plant (NF), productivity (PE), and fresh fruit weight (FW), of Maciel peach trees on different rootstocks in the municipality of Capão do Leão, Rio Grande do Sul, for the 2014/2015 and 2015/2016 harvest seasons.

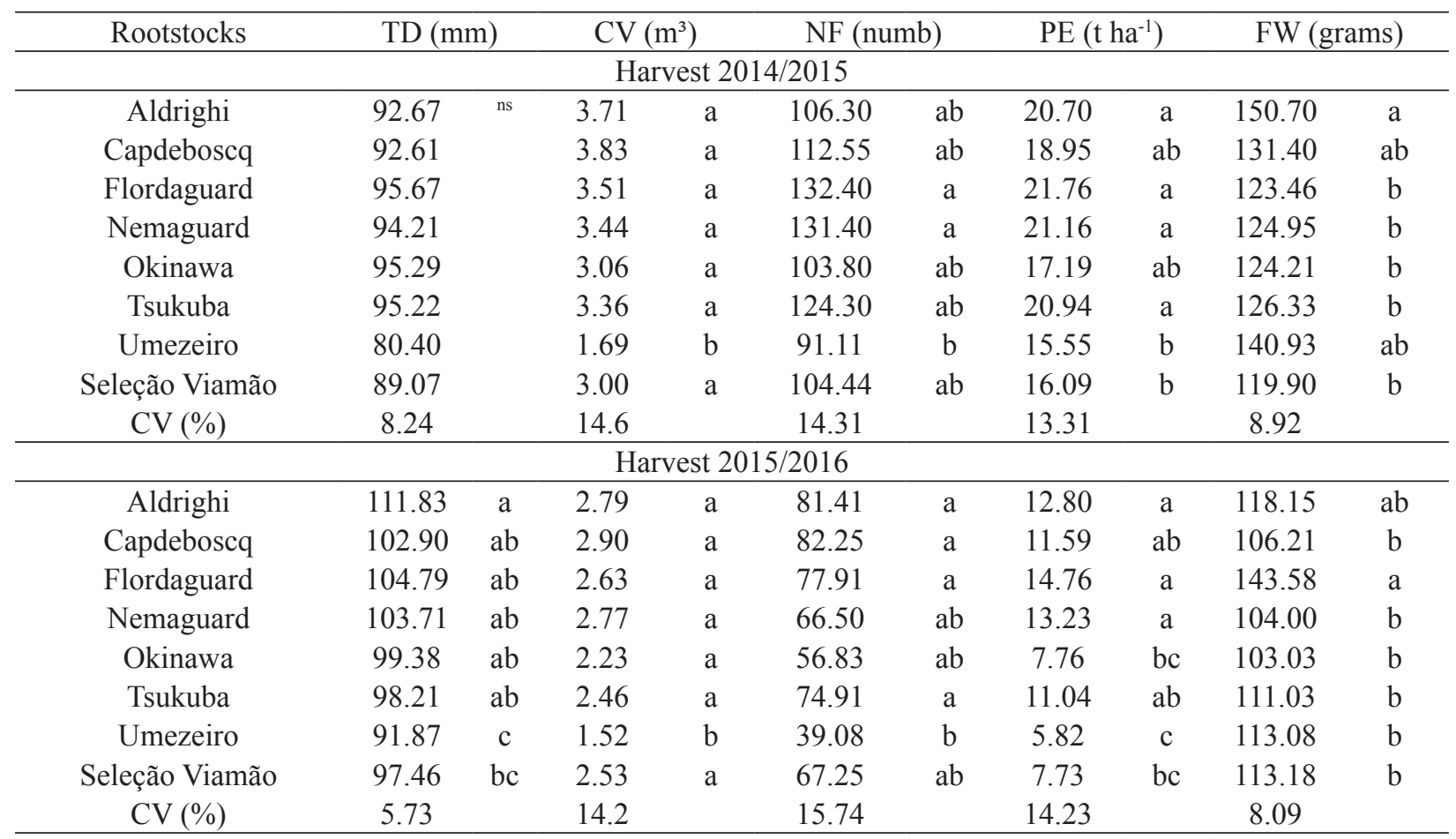

Means followed by the same lowercase letter do not differ significantly from each other $(\mathrm{p} \leq 0.05)$, calculated using Tukey's range test. $\mathrm{CV}(\%)=$ Coefficient of variation. $\mathrm{ns}=$ not significant.

The fresh fruit weight was also affected by the rootstock and harvest season. In the 2014/2015 crop, fruit with the highest mass were harvested from peach trees grafted with Aldrighi, Capdeboscq, and Umezeiro rootstocks while in the 2015/2016 crop fruit with the highest mass came from peach trees with Flordaguard and Aldrighi rootstocks. From this evaluation, the best rootstock in combination with the Maciel cultivar was Aldrighi as it had high fruit productivity and fruit mass in both the harvest seasons. Notably, the low vigor Umezeiro rootstock produced large fruit (140.93 g) in the 2014/2015 harvest season that were similar to those produced by Aldrighi (150.70 g) and Capdeboscq (131.40 g) rootstocks. This was probably because of the lower number of fruit on the peach trees of this rootstock (11.59 kg per plant) compared with Aldrighi and Capdeboscq (15.53 and $14.22 \mathrm{~kg}$ per plant, respectively). It is widely known that a reduction in the number of fruit per plant increases the source/ sink ratio, contributing to the production of larger fruit (DUARTE; PEIL, 2010).

The coloration of the Maciel peach epidermis was also affected by the rootstocks and by factors relating to the harvest season (Table 2). In 2014/2015 season, the fruit of plants grafted to rootstocks Flordaguard $\left(87.28^{\circ} \mathrm{Hue}\right)$ and Nemaguard $\left(88.23^{\circ} \mathrm{Hue}\right)$ were a yellow-green color, while those of plants grafted to Tsukuba $\left(82.27^{\circ} \mathrm{Hue}\right)$ and Umezeiro $\left(82.44^{\circ} \mathrm{Hue}\right)$ were a yellow-orange color. However, in the $2015 / 2016$ crop, all fruit were a yellow-orange color except those harvested from plants grafted to Capdeboscq $\left(85.10^{\circ} \mathrm{Hue}\right)$ that showed yellowgreen coloration. Thus, although epidermis color is important for the fruit of the Maciel cultivar as it can affect in natura consumption, it was not possible to establish a direct relationship between the rootstock used and this variable as the physiological response changed depending on the harvest season. The exact 
cause of this behavior has not been clarified, but it is known that fruit epidermis coloration is strongly affected by genotype (MAYER et al., 2008), by green pruning management (GONÇALVES et al., 2014) and, obviously, by the maturation stage of the fruit (MATHIAS et al., 2008).

Table 2. The color of the epidermis, pulp firmness (PF), total soluble solids (TSS), and titratable acidity (TA) of Maciel peach fruit on different rootstocks in the municipality of Capão do Leão, Rio Grande do Sul, harvested during the 2014/2015 and 2015/2016 seasons.

\begin{tabular}{|c|c|c|c|c|}
\hline Rootstocks & Color $\left({ }^{\circ} \mathrm{Hue}\right)$ & PF (Newtons) & TSS $\left({ }^{\circ}\right.$ Brix $)$ & $\begin{array}{c}\text { TA (\% Citric acid in } 100 \\
\text { g fruit) }\end{array}$ \\
\hline \multicolumn{5}{|c|}{ Harvest 2014/2015 } \\
\hline Aldrighi & $86.85 \mathrm{ab}$ & $33.06 \mathrm{a}$ & $12.83 \mathrm{ab}$ & 0.70 ns \\
\hline Capdeboscq & $86.45 \mathrm{ab}$ & $27.56 \mathrm{bc}$ & $11.46 \mathrm{~b}$ & 0.67 \\
\hline Flordaguard & $87.29 \mathrm{a}$ & $30.35 \mathrm{ab}$ & $12.93 \mathrm{ab}$ & 0.69 \\
\hline Nemaguard & $88.23 \mathrm{a}$ & $26.65 \mathrm{~cd}$ & $12.83 \mathrm{ab}$ & 0.65 \\
\hline Okinawa & $85.35 \mathrm{ab}$ & $26.63 \mathrm{~cd}$ & $14.00 \mathrm{a}$ & 0.65 \\
\hline Tsukuba & $82.27 \mathrm{~b}$ & $24.93 \mathrm{de}$ & $12.30 \mathrm{~b}$ & 0.66 \\
\hline Umezeiro & $82.44 \mathrm{~b}$ & $25.88 \mathrm{cde}$ & $13.20 \mathrm{ab}$ & 0.67 \\
\hline Seleção Viamão & $84.65 \mathrm{ab}$ & $23.13 \mathrm{e}$ & $11.26 \mathrm{~b}$ & 0.63 \\
\hline $\mathrm{CV}(\%)$ & 2.66 & 5.21 & 6.68 & 9.69 \\
\hline \multicolumn{5}{|c|}{ Harvest 2015/2016 } \\
\hline Aldrighi & $86.08 \mathrm{a}$ & $23.34 \mathrm{ab}$ & $10.60 \mathrm{bc}$ & 0.93 ns \\
\hline Capdeboscq & $85.10 \mathrm{~b}$ & $25.93 \mathrm{a}$ & $10.30 \mathrm{c}$ & 0.84 \\
\hline Flordaguard & $87.40 \mathrm{a}$ & $21.84 \mathrm{ab}$ & $11.16 \mathrm{~b}$ & 0.83 \\
\hline Nemaguard & 88.44 a & $20.68 \mathrm{~b}$ & $10.83 \mathrm{bc}$ & 0.85 \\
\hline Okinawa & $86.36 \mathrm{ab}$ & $21.69 \mathrm{~b}$ & $11.80 \mathrm{a}$ & 0.80 \\
\hline Tsukuba & $86.60 \mathrm{ab}$ & $21.82 \mathrm{~b}$ & $10.46 \mathrm{c}$ & 0.79 \\
\hline Umezeiro & $86.14 \mathrm{ab}$ & $21.39 \mathrm{~b}$ & $10.73 \mathrm{bc}$ & 0.87 \\
\hline Seleção Viamão & $86.58 \mathrm{ab}$ & $21.18 \mathrm{~b}$ & $10.76 \mathrm{bc}$ & 0.85 \\
\hline $\mathrm{CV}(\%)$ & 0.88 & 6.45 & 3.13 & 6.57 \\
\hline
\end{tabular}

Means followed by the same lowercase letter do not differ significantly from each other $(\mathrm{p} \leq 0.05)$, calculated using Tukey's range test. $\mathrm{CV}(\%)=$ Coefficient of variation. $\mathrm{ns}=$ not significant.

The highest firmness of peach pulp was observed in peaches harvested from Aldrighi and Flordaguard rootstocks in the 2014/2015 harvest season and Aldrighi, Capdeboscq, and Flordaguard rootstocks in the 2015/2016 harvest season. Similar to epidermis color, pulp firmness is a consequence of many factors, such as genotype, phytotechnical management, nutrition, and maturation stage (ALCOBENDAS et al., 2012).

In addition to the changes observed in fruit color and firmness, changes in total soluble solids between harvests were also observed. Along with the rootstocks Umezeiro, Flordaguard, Nemaguard, and
Aldrighi, the Okinawa rootstock produced Maciel peaches with high concentrations of soluble solids in the 2014/2015 crop. However, in the 2015/2016 harvest, the Okinawa rootstock produced peaches with greater concentrations of soluble solids than these other rootstocks. The best combination in terms of soluble solids across these two harvest seasons, therefore, was the Maciel cultivar with the Okinawa rootstock. When combined with the cultivars Talismã and Tropical, this rootstock also produced fruit with greater soluble solids (MONTES et al., 2008). Regardless of the rootstock studied, the titratable acidity of the fruit did not 
differ significantly at the time of harvest for either harvest period.

The highest firmness of peach pulp was observed in peaches harvested from Aldrighi and Flordaguard rootstocks in the 2014/2015 harvest season and Aldrighi, Capdeboscq, and Flordaguard rootstocks in the 2015/2016 harvest season. Similar to epidermis color, pulp firmness is a consequence of many factors, such as genotype, phytotechnical management, nutrition, and maturation stage (ALCOBENDAS et al., 2012).

In addition to the changes observed in fruit color and firmness, changes in total soluble solids between harvests were also observed. Along with the rootstocks Umezeiro, Flordaguard, Nemaguard, and Aldrighi, the Okinawa rootstock produced Maciel peaches with high concentrations of soluble solids in the 2014/2015 crop. However, in the 2015/2016 harvest, the Okinawa rootstock produced peaches with greater concentrations of soluble solids than these other rootstocks. The best combination in terms of soluble solids across these two harvest seasons, therefore, was the Maciel cultivar with the Okinawa rootstock. When combined with the cultivars Talismã and Tropical, this rootstock also produced fruit with greater soluble solids (MONTES et al., 2008). Regardless of the rootstock studied, the titratable acidity of the fruit did not differ significantly at the time of harvest for either harvest period.

The concentrations of the major groups of phytochemical compounds (total phenols, total carotenoids, and antioxidant activity) varied depending on the rootstock used for both harvests (Table 3), and between the two harvest seasons. Peaches harvested in the 2014/2015 season from plants grafted to the Aldrighi rootstock showed the highest accumulation of phenolic compounds and differed significantly only from Tsukuba that presented the lowest mean. In the 2015/2016 season, the highest concentration of total phenols was observed in fruit harvested from Okinawa rootstocks that differed significantly only from Tsukuba and Nemaguard that had the lowest means. Thus, the Tsukuba rootstock was associated with the lower production of phenols in fruit.

The fruit of plants grafted to the Nemaguard rootstock had significantly higher carotenoid levels in both harvests compared with the other rootstocks. Overall, fruit from the 2014/2015 harvest had the highest carotenoid averages for each rootstock except Flordaguard when compared with the subsequent harvest, although high carotenoid concentrations were also obtained in the 2015/2016 harvest for Capdeboscq, Aldrighi and Flordaguard, and Nemaguard (Table 3).

In the 2014/2015 crop, antioxidant activity in peach pulp was higher in the fruit of plants grafted to Okinawa, Aldrighi, Umezeiro, Capdeboscq, Flordaguard, and Nemaguard rootstocks than Tsukuba and Seleção Viamão. These phytochemical compounds are the main agents influencing the antioxidant potential of yellow pulp peaches (SANTOS et al., 2013). In the 2015/2016 crop, fruit from the Okinawa and Flordaguard rootstocks had the highest concentrations of antioxidant activity. The antioxidant activity of the Okinawa rootstock was similar across the two harvest seasons (Table 3).

The results of this study indicate that phytochemical concentration is not clearly associated with rootstock or harvest season, suggesting that the relationship between canopy cultivar and rootstock has not been well established in terms of phytochemicals. The use of different rootstocks has previously been shown to alter phytochemical concentrations in peaches in studies by Picolotto et al. (2009), Remorini et al. (2008), and Forcada et al. (2013). However, phytochemical concentration can also be altered by plant management, fruit maturation, the position of the fruit on the plant, genotype (REMORINI et al., 2008), environmental condition, and harvest season (FORCADA et al., 2013). 
Table 3. Total phenols, total carotenoids, and antioxidant activity in the pulp of Maciel peaches from different rootstocks in the municipality of Capão do Leão, Rio Grande do Sul, harvested during the 2014/2015 and 2015/2016 seasons.

\begin{tabular}{|c|c|c|c|}
\hline Rootstocks & Total phenols ${ }^{1}$ & Total carotenoids $^{2}$ & Antioxidant activity $^{3}$ \\
\hline \multicolumn{4}{|c|}{ Harvest 2014/2015 } \\
\hline Aldrighi & $147.19 \mathrm{a}$ & $55.65 \mathrm{ab}$ & $374.41 \mathrm{a}$ \\
\hline Capdeboscq & $105.83 \mathrm{ab}$ & $67.76 \mathrm{ab}$ & $330.07 \mathrm{ab}$ \\
\hline Flordaguard & $109.16 \mathrm{ab}$ & $42.47 \mathrm{~b}$ & $263.71 \mathrm{ab}$ \\
\hline Nemaguard & $105.58 \mathrm{ab}$ & $76.00 \mathrm{a}$ & $255.09 \mathrm{ab}$ \\
\hline 'Okinawa' & $119.33 \mathrm{ab}$ & $69.24 \mathrm{ab}$ & $395.10 \mathrm{a}$ \\
\hline 'Tsukuba' & $83.22 \mathrm{~b}$ & $44.56 \mathrm{ab}$ & $183.55 \mathrm{~b}$ \\
\hline 'Umezeiro' & $129.23 \mathrm{ab}$ & $52.14 \mathrm{ab}$ & $364.99 \mathrm{a}$ \\
\hline 'Seleção Viamão & $114.32 \mathrm{ab}$ & $52.12 \mathrm{ab}$ & $177.74 \mathrm{~b}$ \\
\hline CV (\%) & 14.26 & 18.09 & 17.27 \\
\hline \multicolumn{4}{|c|}{ Harvest 2015/2016 } \\
\hline Aldrighi & $194.38 \mathrm{ab}$ & $42.24 \mathrm{ab}$ & 270.98 bc \\
\hline Capdeboscq & $187.14 \mathrm{ab}$ & $59.32 \mathrm{a}$ & $265.94 \mathrm{bc}$ \\
\hline Flordaguard & $224.86 \mathrm{ab}$ & $44.51 \mathrm{ab}$ & $379.41 \mathrm{ab}$ \\
\hline Nemaguard & $172.46 \mathrm{~b}$ & $60.15 \mathrm{a}$ & $234.26 \mathrm{c}$ \\
\hline Okinawa & $242.70 \quad \mathrm{a}$ & $38.19 \mathrm{~b}$ & $428.69 \mathrm{a}$ \\
\hline Tsukuba & $158.56 \mathrm{~b}$ & $37.49 \mathrm{~b}$ & $187.49 \mathrm{c}$ \\
\hline Umezeiro & $202.22 \mathrm{ab}$ & $33.90 \mathrm{~b}$ & 220.49 c \\
\hline Seleção Viamão & $217.31 \mathrm{ab}$ & $37.43 \mathrm{~b}$ & $270.55 \mathrm{bc}$ \\
\hline CV $(\%)$ & 11.94 & 14.81 & 17.81 \\
\hline
\end{tabular}

${ }^{1} \mathrm{mg}$ Gallic acid equivalent $100 \mathrm{~g}^{-1}$ fresh weight. ${ }^{2} \mu \mathrm{g}$ equivalent $\beta$-carotene $100 \mathrm{~g}^{-1}$ fresh weight. ${ }^{4} \mathrm{mg}$ equivalent trolox $100 \mathrm{~g}^{-1}$ fresh weight.

Means followed by the same lowercase letter do not differ significantly from each other $(\mathrm{p} \leq 0.05)$, calculated using Tukey's range test. $\mathrm{CV}(\%)=$ Coefficient of variation. $\mathrm{ns}=$ not significant.

\section{Conclusion}

Use of the Umezeiro rootstock with the Maciel cultivar results in peach trees with low vigor, smaller trunk diameter, and reduced canopy volume.

The Aldrighi, Capdeboscq, Flordaguard, Nemaguard, and Tsukuba rootstocks grafted to Maciel peach trees had higher productivity and produced greater numbers of fruit.

The rootstock influences the flowering period of the Maciel cultivar and may delay flowering or cause earlier subperiods of flowering.

The rootstock affects the fruit epidermis color and the pulp firmness, soluble solids content, total phenols, antioxidant activity, and total carotenoids in Maciel peaches.

\section{References}

ALCOBENDAS, R.; MIRAS-AVALOS, J. M.; ALARCÓN, J. J.; PEDRERO, F.; NICHOLAS, E. Combined effects of irrigation, crop load and fruit position on size, color and firmness of fruits in extra-early cultivar of peach. Scientia Horticulturae, Alexandria, v. 142, n. 1, p. 128-135, 2012.

ASSOCIATION OF OFFICIAL ANALYTICAL CHEMISTS - AOAC. Official methods of analysis. Arlington VA, USA, 2005.

BRAND-WILLIAMS, W.; CUVELIER, M. E.; BERSET, C. Use of a free radical method to evaluate antioxidant activity. Food Science and Technology, Campinas, v. 28, n. 1, p. 25-30, 1995.

COMIOTTO, A.; FACHINELLO, J. C.; HOFFMANN, A.; GALARÇA, S. P.; MACHADO, N. P.; PREZOTTO, M. E.; HASS, L. B. Desenvolvimento, produção e qualidade dos frutos de pessegueiros enxertados sobre diferentes porta-enxertos. Semina: Ciências Agrárias, Londrina, v. 34, n. 6, p. 3553-3562, 2013. Suplemento 1. 
COMIOTTO, A.; FACHINELLO, J. C.; HOFFMANN, A.; MACHADO, N. P.; GALARÇA, S. P.; BETEMPS, D. L. Vigor, floração, produção e qualidade de pêssegos 'Chimarrita' e 'Maciel' em função de diferentes portaenxertos. Ciência Rural, Santa Maria, v. 42, n. 5, p. 788794, 2012.

DUARTE, T. S.; PEIL, R. M. N. Relações fonte: dreno e crescimento vegetativo do meloeiro. Horticultura Brasileira, Brasília, v. 28, n. 3, p. 271-276, 2010.

FORCADA, C. F.; GOGORCENA, Y. J.; MORENO, M. A. Fruit sugar profile and antioxidants of peach and nectarine cultivars on almond $\times$ peach hybrid rootstocks. Scientia Horticulturae, Amsterdam, v. 164, n. 2, p. 563572, 2013.

GALARÇA, S. P.; FACHINELLO, J. C.; BETEMPS, D. L.; HOFFMANN, A.; MARODIN, G. A. B.; PRETTO, A. N.; SILVA, F.; DIAS, F. P. Crescimento e desenvolvimento de pessegueiros 'Chimarrita' e 'Maciel' sobre diferentes porta-enxertos e locais de cultivo. Ciência Rural, Santa Maria, v. 43, n. 2, p. 219-224, 2013.

GONÇALVES, M. A.; PICOLOTTO, L.; AZEVEDO. F.Q.; COCCO, C.; ANTUNES, L. E. C. Qualidade de fruto e produtividade de pessegueiros submetidos a diferentes épocas de poda. Ciência Rural, Santa Maria, v. 44, n. 8, p. 1334-1340, 2014.

INSTITUTO BRASILEIRO DE GEOGRAFIA E ESTATÍSTICA - IBGE. Produção agrícola municipal. Rio de Janeiro: IBGE, 2017. Disponível em: $<$ http://www. sidra.ibge.gov.br/bda/tabela/protabl.asp?c $=1613 \& z=$ p\&o=24\&i=P.>. Acesso em: 06 de nov. 2015.

MATHIAS, C.; MAYER, N. A.; MATTIUZ, B. H.; PEREIRA, F. M. Efeito de porta-enxertos e espaçamentos entre plantas na qualidade de pêssegos 'Aurora'. Revista Brasileira de Fruticultura, Jaboticabal, v. 30, n. 1, p. 165-170, 2008.

MAYER, N. A.; BIANCHI, V. J.; CASTRO, L. A. S. Porta-enxertos. In: RASEIRA, M. do C. B.; PEREIRA, J. F. M.; CARVALHO, F. L. C. (Ed.). Pessegueiro. Brasília: Embrapa Clima Temperado, 2014. p. 172-223.

MAYER, N. A.; MATTIUZ, B.; PEREIRA, F. M. Qualidade pós-colheita de pêssegos de cultivares e seleções produzidos na microrregião de Jaboticabal-SP. Revista Brasileira de Fruticultura, Jaboticabal, v. 30, n. 3, p. 616-621, 2008.

MONTES, S. M.; BOLIANI, A. C.; RAGA, A., SANTOS, P. C.; CORRÊA, L. S.; FERRARI, J. T. Características produtivas, físicas e químicas de frutos de cultivares de pessegueiros sobre dois porta-enxertos no oeste do estado de São Paulo. Revista Brasileira de Fruticultura, Jaboticabal, v. 30, n. 4, p. 1065-1070, 2008.
PICOLOTTO, L.; MANICA-BERTO, R.; PAZIN, D.; PASA, M. da S.; SCHMITZ, J.D.; PREZOTTO, M.E.; BETEMPS, B.; BIANCHI, V.J.; FACHINELLO, J.C. Características vegetativas, fenológicas e produtivas do pessegueiro cultivar Chimarrita enxertado em diferentes porta-enxertos. Pesquisa Agropecuária Brasileira, Brasília, v. 44, n. 6, p. 583-589, 2009.

RASEIRA, M. do C. B.; NAKASU, B. H.; BARBOSA, W. Cultivares: descrição e recomendação. In: RASEIRA, M. do C. B; PEREIRA, J. F. M.; CARVALHO, F. L. C. (Ed.). Pessegueiro. Brasília: Embrapa Clima Temperado, 2014. p. 73-142.

REMORINI, D.; TAVARINI, S.; DEGL'INNOCENTI, E.; LORETI, F.; MASSAI, R; GUIDI, L. Effect of rootstocks and harvesting time on the nutritional quality of peel and flesh of peach fruits. Food Chemistry, Oxford, v. 110, n. 2, p. 361-367, 2008.

ROCHA, M. S.; BIANCHI, V. J.; FACHINELLO, J. C.; SCHMITZ, J. D.; PASA, M. S.; SILVA, J. B. Comportamento agronômico inicial da cv. Chimarrita enxertada em cinco porta-enxertos de pessegueiro. Revista Brasileira Fruticultura, Jaboticabal, v. 29, n. 3, p. 583-588, 2007.

ROSSI, A; FACHINELLO, J. C.; RUFATO, L.; PARISOTO, E.; PICOLOTTO, L.; KRUGER, L. R. Comportamento do pessegueiro 'Granada' sobre diferentes porta-enxertos. Revista Brasileira de Fruticultura, Jaboticabal, v. 26, n. 3, p. 446-449, 2004.

SANTOS, C. M. dos; ABREU, C. M. P. de; FREIRE, J. M.; CORREA, A. D. Atividade antioxidante de frutos de quatro cultivares de pessegueiro. Revista Brasileira de Fruticultura, Jaboticabal, v. 35, n. 2, p. 339-344, 2013.

SCHMITZ, J. D.; BIANCHI, V. J.; PASA, M. P.; SOUZA, A. L. K.; FACHINELLO, J. C. Vigor e produtividade do pessegueiro 'chimarrita' sobre diferentes porta-enxertos. Revista Brasileira de Agrociência, Pelotas, v. 18, n. 4, p. 1-10, 2012.

SINGLETON, V. L.; ROSSI, J. A. J. R. Colorimetry of total phenolic with phosphomolybdic-phosphotungstic acid reagents. American Journal of Enology and Viticulture, Davis, v. 16, n. 3, p. 144-158, 1965.

TOMBESI, S.; ALMEHDI, A.; DEJONG, T. M. Phenotyping vigour control capacity of new peach rootstocks by xylem vessel analysis. Scientia Horticulturae, Amsterdam, v. 127, n. 3, p. 353-357, 2011. 
